\title{
Dynamics of Collaboration: The Case of Finnish and American Aerosol Research Groups
}

\author{
Eveliina Saari
}

Sciencehas been said to beboth a highly competitive and highly cooperative affair (Hull, 1988: 286). Scientists form informal alliances, use each other's research results, and disseminate their own results through scientific interaction. Cooperation between rivals in the field of research and development work has been studied by managementscientists (e.g.,von Hippel, 1987; Sinha \& Cusumano, 1991; Dickson, 1996; Teichert, 1997). Their interest has focused on predicting the success of joint research venturesor informal know-how trading, using quantitative cost-benefit models. Their conclusionsstress important factors for starting a collaboration, such as the observation that "complementary skills and resources appear to be the most important factor influencing a firm's decision to participate in a joint research venture" (Sinha \& Cusumano, 1991:1098). These studies are based on interviews with the man- agement staff only. The interactions between the collaborators or rivals are not described or analyzed.

Previous studies on research collaboration have examined questions, such as, how one can measure research collaboration, what factors or sources encourage the formation of research collaborations, and what kind of effects doescollaboration haveon productivity and on theimpact of joint research (Katz \& Martin, 1997). Multiple-author publications (e.g., Meadows \& O'Connor, 1971), physical proximity of collaborators (e.g., Kraut et al., 1990), and the number of scientific papers published (e.g., Pao, 1981) have all been used as quantitativeindicators of joint research. In thesestudies, the general overall conditions of collaboration are outlined. However, the interaction process itself and the dynamics of change in the research relationships, still remain to be analyzed. 
The elusive dynamics of cooperation and competition in science are a phenomenon that could be best captured by case-studies. Atkinson, Batchelor and Parsons (1998) have recently examined the relationships between different research groups during a process of a medical discovery. Using ethnographic fieldwork methods and in-depth interviews they describe the changing relations between the collaborators. They define the process as an exchange of material resources and expertise between different research groups that make specific contributions to the overall research effort (Atkinson et al., 1998: 267). In the present paper, I also use an ethnographic approach and concentrate on the evolution of a collaborational dyad - a cooperation between two research groups. The research groups are from the Technical Research Center in Espoo, Finland and from the University of New Mexico, Albuquerque, USA. Both groups were founded at the beginning of the 1990s, and are well-known in the field of aerosol research.

The theoretical starting point of this study is the notion that collaboration is both historically and locally formed, and a situationally constituted activity. I shall analyze the evolution of the collaboration between the Finnish and the American research groups against their own developmental trajectories, specifically, the discourse and interaction between the research group leaders. In the analysis, I have followed the model of analyzing conversations presented by Michael Lynch (1985). The content and outcome of the interaction becomes more prominent in the analysis, than its form, although the interaction is presented in as detailed a manner as possible from the videotape. $^{1}$

Thecultural-historical theory of activity offers a framework to study research collaboration in terms of object-oriented activity (Engeström et al., 1991; Miettinen, 1998). According to activity theory, human action is mediated by cultural means, that is, signs and material tools (Vygotsky, 1978). The activity of a research group is analyzed in this study as mediated activity, which consists of three interactive elements: subject (researchers), means (devices, knowledge, theories), and object ${ }^{2}$. Through the object, an activity gains its purpose and motive. When two research groups collaborate, their shared object is something that both groups have selected as an object of construction and transformation. The unstable relations within collaboration and competition between the research groups become visible when analyzing changes in their means and research objects.

Thecultural-historical theory of activity understands collaboration in a historical perspective, which means that, such aspects making collaboration evolve, change or end, come into focus in the study. The history of the collaborating activity systems has an influence on the quality of their mutual interaction. However, it is only in the interaction where the emerging tensions in the collaboration either culminate or are dealt with. In this study, interaction between organizations or people is interpreted notonly by analyzingtheconceptions of the participants, but is also derived from multiple data such as interviews, observation of interactional situations and the joint articles published, as a result of the collaboration.

I will analyze the evolution of a col- 
laboration between a Finnish research group and an American research group, from 1992-1997. My guiding questions are: 1)what makes collaboration between two research groups end?2) what happens in an interaction between the group leaders, when their research groups have followed different developmental trajectories? In order to understand the change in collaboration, the history of each group is first outlined.

\section{The History of the Finnish Research Group}

The Aerosol Technology Group (ATG) is located in the city of Espoo, at the Technical Research Centre of Finland (VTT), which is a governmental research institute within the Ministry ofTrade and Industry. The number of VTT personnel is about 2700,1300 of which are researchers. VTT does applied technical research in several fields of technology. Its funding comes from the state budget (40\%), from public and international funding sources (30\%) and from contract research (30\%).

The Years Before the Founding of the Aerosol Technology Group

The Aerosol Technology Group was founded atVTT by two young physicists in 1990. Before startinga research group of their own, both physicists had studied in the Aerosol Physics Group at the University of Helsinki. In the middle of the 1980s, they had both worked for about a year in American research laboratories. While doing research work of their own, they were also able to learn the American way of managing a research group.
A significant strength of the research group, was that the two founders' areas of expertise were complementary. One did his dissertation about the measurement method for the sizedistribution of aerosol particles, and the other wrote about modeling aerosols in a hypothetical nuclear reactor accident. When the two researchers started working together, they began to construct a new model: Aerosol Behavior in Combustion $(A B C)$. The principle of the model was that the measurement data could becalculated by a computer model and thus theaerosol dynamics in the combustion reactors could be predicted. Compared with the other aerosol research groups, it was rare to have both the experimentation and modeling know-how in the same group. Another benefit was that both group leaders could recruit new researchers with either a modeling or experimenting background and form new research projects around their own expertise.

The two leaders did not mind the organizational borders in their act of founding a common group. Originally, they belonged to two different laboratories inside the VTT. Today, about half of the research group belongs to VTT Energy and the other half to VTT Chemical Technology, but to outsiders it appears to be one coherent research group.

From the Birth of the Research Group to the Phase of Growth (1991-1994)

The birth and growth of the Aerosol Technology Group started from ground level. The research group had to createa clear identity, a name and a research program for itself, in order to emphasize the relevance of, and need for, aerosol 
research to themanagement of $\mathrm{VTT}$ and to the outside funding agencies. The Aerosol Technology Group specialized in researching aerosols (suspensions of small solid or liquid particles in gas) at high temperatures. Owing to the background of its leaders, the first two application areas or objects were aerosol dynamics in industrial combustion processes and in severe nuclear reactor accidents. The idea of producing new nanosized particles for material applications by aerosol method wasintroduced to the leaders at international aerosol meetings in the beginning of the 1990s. Although the leaders did not yet have proper research equipment to start producing particles, such as an aerosol reactor, they decided that it would be a potential application area for the group. As the analysis will show later on, producing particles for material applications was also theareain which theFinnish and the American research groups started their collaboration.

The Aerosol Technology Group expanded rapidly during the earlynineties. In 1990, the group had only five researchers, but by 1993 the group had grown to 14 researchers. The two group leaders recruited new researchers fresh from the universities and formed a management model, in which the two group leaders acted as project managers of all the ongoing and forthcoming research projects. The researchers were at first recruited for one year temporary projects, but their posts usually became permanent after that. The researchers wereencouraged to do their dissertation studies at the same time as they participated in theprojects, and thus thegroup leaders tried to protect them from too much project bureaucracy. Thestructure of the research group at VTT resembled the American university model of a professor guiding the work of several graduate students.

Constructing the Aerosol Laboratory and Managing the Heterogeneous Research Program (1995-1997)

In the preliminary phases, the Aerosol Technology Group did not have laboratory space of its own, thus the equipment was in the corners of other VTT laboratories. Because the aerosol measurements were usually made under field circumstances, for instance, in power plants or with pilot scale coal combustion reactors located abroad, the measurement devices traveled with the researchers from place to place. Further analysis of the collected particlesamples was made at the VTT lab and at the nearby universities. Electron microscopy was one of the crucial techniques in aerosol research, in order to make the tiny particles studied visible. Theleader of the ATG traveled to the USA once or twice a year and used the electron microscopes of the University of New Mexico to analyzethe wholegroup's particle samples. It was only in the beginning of 1995 that ATG was assigned three laboratory rooms at VTT. A technician was hired to maintain the laboratory in the beginning of 1996. Electron microscopes were acquired for the group in the spring of 1996 and spring of 1997.

TheATG worked within several application areas, covering combustion processes, severe nuclear reactor accidents and producing new materials. Consequently, its research program was heterogeneous and the network of collaborators was wide. Forming new projects 
and finding new application objects kept the two leaders very busy. However, at the same time, the group of 18 researchers also needed guidance and tutoring. The researchers of the ATG expressed their dissatisfaction about the insufficient support of their dissertation studies. This turned into tension about how to manage a growing research group. During 1996 and 1997, the group recruited two postdoctoral fellows from abroad. It was hoped that they would share the burden of tutoring, which had formerly been undertaken by the two leaders.

\section{The History of the American Research Group}

The American research group is located in the Center for Micro-Engineered Materials (CMEM), at the University of $\mathrm{New}$ Mexico in Albuquerque. CMEM was founded in 1988, and isone of thel ndustry-University Cooperative Research Centers funded by the National Science Foundation. The center combines the technical resources of the University of New Mexico, and the Sandia and Los Alamos National Laboratories. CMEM is a small organization, which operates as a coordinating liaison between the university and industry. According to their own brochure: "The center is responsive to the needs and interests of its industrial members, who, in conjunction with theresearch faculty, determinethe number, type and funding of its research projects." In 1997, the center had ten industrial member companies involved.

Forming a Research Group (1988-1990)

The Vapor Phase Synthesis of Powders and Films-research group began to form around Assistant ProfessorT in 1988. He received hisPh.D. in Chemical Engineering, and before coming to the University of New Mexico, had worked for two years at the IBM Research Division. The starting point of the American group was similar to the Finnish case. Along with Professor $T$ there was a Professor of Chemistry, $M$, who had also joined the CMEM in 1988. Although the two professors began to form research groups of their own, they started to collaborate early in their careers at the university. They conducted about half of their research proposals together, jointly hired some of the postdoctoral fellows, and often arranged joint meetings.

The two professors' expertise was complementary. The Professor of Chemistry $(M)$ was an expert on chemistry of molecules used as precursors, while the Professor of Chemical Engineering $(T)$ was an expert on the kinetics of vapor phase reactions. Both of these areas are important when you have a liquid precursor and want to transform it in an aerosol reactor to small solid particles of a certain material.

The research area of the American group wasto produce new powders and films for micro-electronic applications and catalytic applications. The entire American group was working on making improved materials using aerosol synthesis, and was more knowledgeable in this area than the Finnish group, who were only planning to expand to the materials area in the beginning of the 1990s.

The management philosophy of the American group emphasized the usability of the research resultsin an industrial sense. According to Professor T, the po- 
sition of his group could be described as ephemeral, which means the postdoctoral researchers and graduate students did not have permanent posts. The group was a loose-knit bunch of graduate students and postdoctoral fellows, who worked with and for the professor. Thegroup did not have an official name such as the Finnish group. However, in this paper the group is called the Vapor Phase Synthesis of Powders and Films Group.

Growth of the Research Group and Founding a Spin-off Firm (1991-1994)

The American research group grew rapidly. In 1991, there were sixpostdoctoral fellows, three graduate, and six undergraduatestudents. The most productive year for the group was 1992, when the researchers wrote 21 refereed publications. At that time, a technical editor was hired to finalize the publications of the researchers. From 1990 until 1995, the Professor $\mathrm{T}$ was a popular lecturer both in the States and internationally in the field of aerosol technology. He had 19 invited academic presentations, 9 invited conference presentations and 10 invited industrial presentations during those years ${ }^{3}$.

In 1992, Professors M and T started a company of their own. At the University of New Mexico, professors were allowed to use one day a week for consultingjobs or for their own businesses. The Professor of Chemistry described their motivation to found a firm as follows:

The university is not a vehicle to be more strongly involved with the real world with getting technology commercialized. In 1992, we started this company mainly because peoplewere calling us and asking: Can you make a kilogram of this precursor? And they were asking things that were not appropriate for us to do in the university. In theUS, for last 10 years, there has been a strong push to transfer technology from fundamental research to industry. But there is no real vehicle to do that, so industry is trying not to spend too much of its money on fundamental $R \& D$. The university is spending most of its time on fundamental $R \& D$, but they can't spend too much time commercializing it, because graduate students cannot put that in their Ph.D. the ses. So there needs to be some vehicle to go between the university and industry. It made sense for us to start a small business. And that allows us to accept somefunds to do things that don't necessarily lead to students' education. (M/ 14.3.1997)

The spin-off firm started to scale-up the aerosol method of producing particles, in order to make it into an industrially appropriate production method. A large chemical company, DuPont, supported the professors in starting a firm, which would make certain metal particles for thick-film pastes on a larger scale.

\section{Growth of the Spin-off-Firm (1995-1997)}

Onedifference, compared with theFinnish research group, was that the American research group systematically obtained patents for their methods to produce certain particles. In 1997, Professor $\mathrm{T}$ was involved in nine patents awarded. As the leader of the American research group, hehad to dividehis time between managing a research group as well as a growingstart-up firm. From the graduatestudents' perspective, this created a problem, becausehehad less time for the research group and tutoring of their studies were suffering. Some of the 
graduate students were also working from time to time for the firm, which slowed down their own studies.

In 1997, the Professor T did not take new students into the group. Duringthat year, two of the postdoctoral researchers and three of the graduate students wereemployed by thestart-up company. The professor took a year off from the university, in January 1998, in order to concentrate on the start-up company, and thus the research group ended.

Collaboration between the Research Groups Beginning in 1992

All in all, the developmental phases of the Finnish and the American research groups are quite different. One way to describethetrajectories of the groups is to look at how the number of research- ers has varied from year to year. Figure 1 shows how the number of researchers (including the leaders, postdoctoral fellows, graduate students and undergraduate students) has changed during ten years in both groups. In addition, the start-up company founded by the two American professorsismarked in the figure.

The first time the leaders of the Finnish research group and the leader of the American group met, was in 1991, at an international aerosol meeting. Both groups were young and in their growing phase, eager to expand their scientific networks. The group leaders were also about the same age, which made it easy to start a collaboration. By 1997, the paths of the groups seemed to have changed into different directions; the Finnish group continued to grow, while

Figure 1. The number of researchers in the Finnish and in the American research groups from 1988-1998

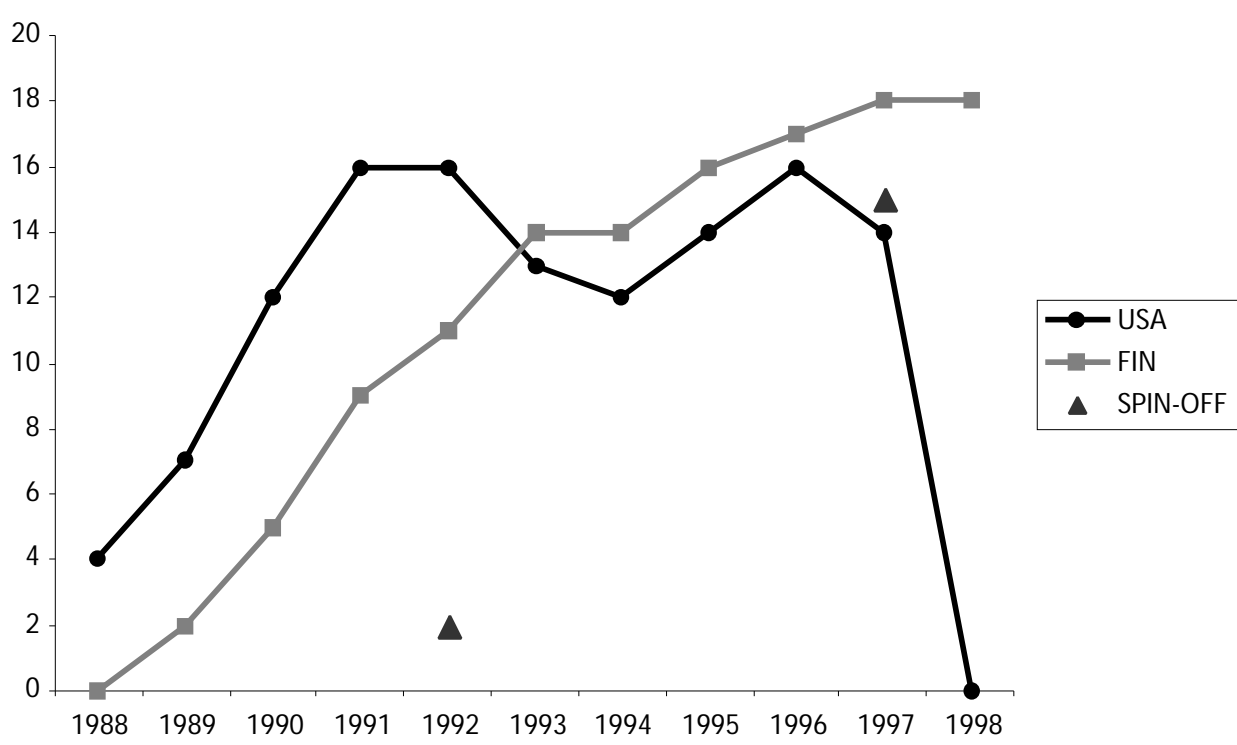


Figure 2. Main interactions between the Finnish and the American research groups from 1991-1998

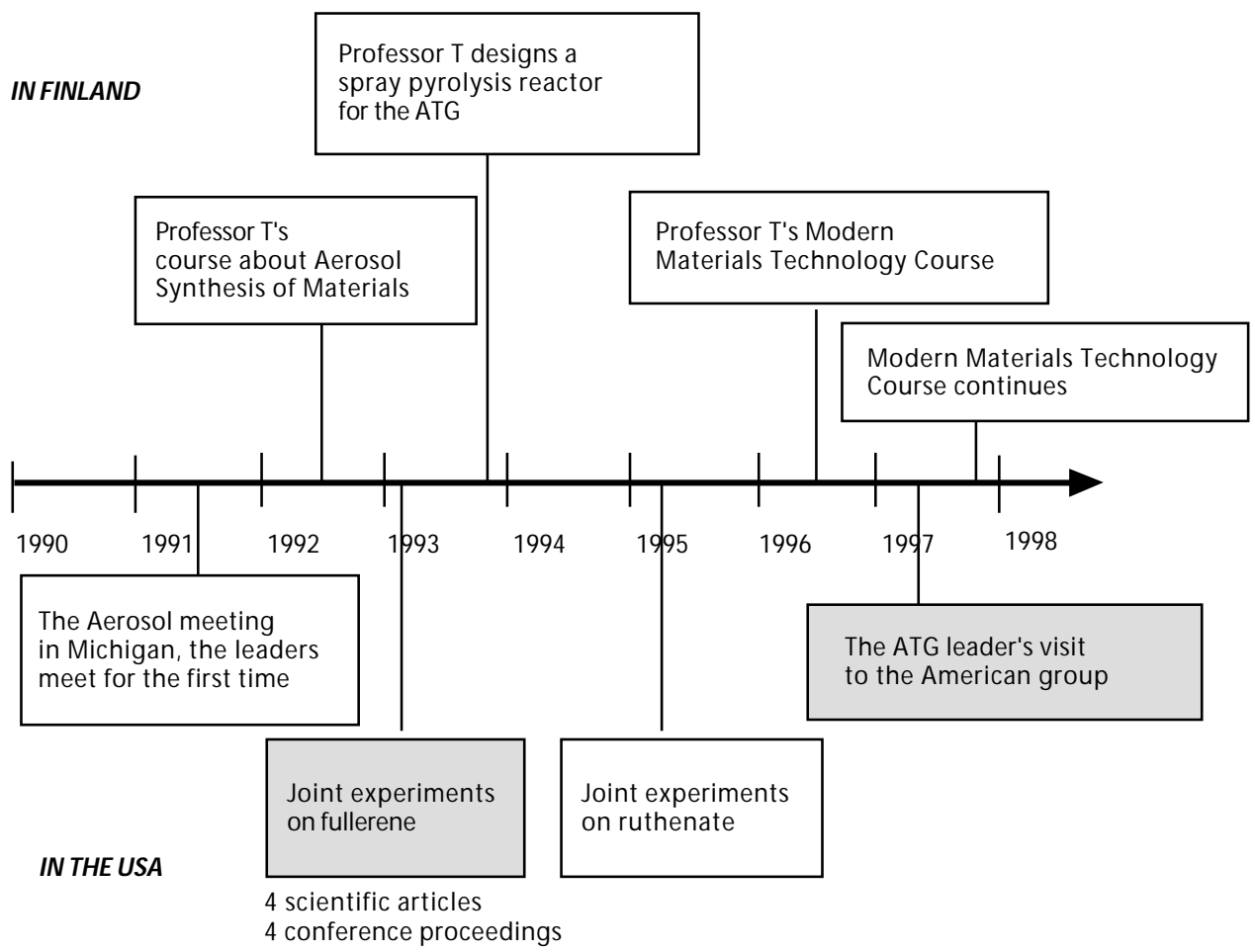

the American group was intentionally down-sized. Figure 2 describes what kind of interaction the Finnish and the American groups had during their collaboration.

Collaboration between the American and the Finnish research groups started at the initiative of the Finns. The group leaders of the ATG decided that they would ask for the help of the American researchers to begin to investigate a new research area, the aerosol synthesis of materials. Since the early 1990s, the two leaders of the ATG had participated in the international aerosol conferences in theUSA. Theleadersof the ATG regarded the conferences as having given them an opportunity to survey the most recent trends in aerosol research. At these conferences, they had timeto plan together how to expand their research and how to start collaboration with other research groups.

During an international aerosol conference in 1991, the ProfessorT from the University of New Mexico was invited to give a course to theVTT's Aerosol Technology Group, about the vapor phase synthesis of materials. The course was organized in June 1992, in Finland. At that time, the ATG did not have research facilities to start experiments on the aerosol synthesis of materials in their own laboratory. They did not have the material reactors, nor the electron microscopes necessary for observing the 
nanosized particles ${ }^{4}$. But the ATG's expertise was in the use of aerosol measurement devices in difficult high-temperature conditions.

Duringhis visit to Finland, theAmerican Professor T agreed on collaboration with the VTT's Aerosol Technology Group. They decided to start experiments on the production of fullerenes and superconducting powders. The choice of these materials derived mainly from the American group's interest. The leader of the ATG and one researcher took their aerosol measurement devices to the University of New Mexico for two weeks in January 1993. The results of these experiments were reported in four joint conference proceedings and in four scientific articles in 1993-1995 (see e.g., Gurav et al., 1994). Figure 3 shows the complementary instruments and knowledge that were used in joint experiments and exchanged between the two groups. The research groups are depicted as mediated activity systems (triangles) and the collaboration between them is composed of complementary instruments and knowledge related to the shared object.

The Finnish group had much to learn from the American group. The knowhow that the American group could teach to the leader and the researcher of ATG concerned using the aerosol material reactors for producing particles. The joint experiments were an opportunity for the Finns to learn how to run a spray pyrolysis reactor. A graduate student of the American group described:

Similarly, in the lab you just go and you start working with your hands. A little bit [of] supervision and advice you

Figure 3. Exchange of instrumental know-how and the shared object between the American and the Finnish aerosol research groups from 1992-1994

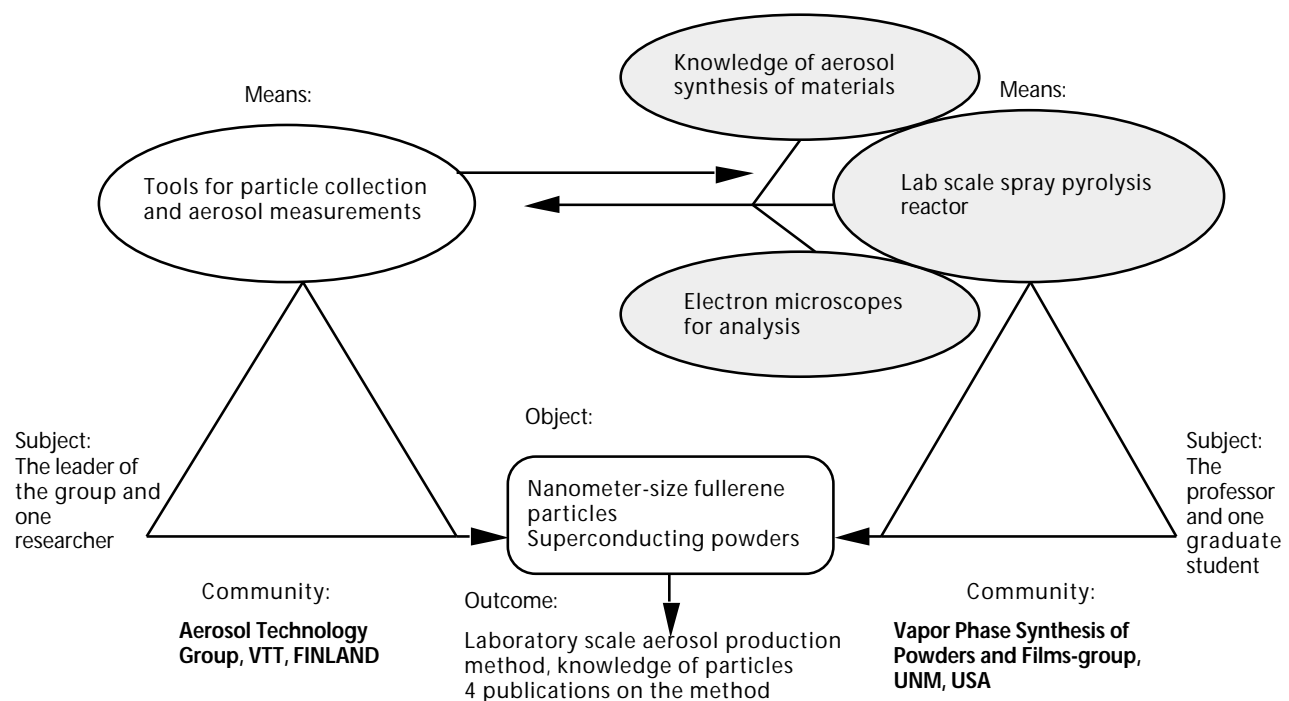


need here and there.You know, different tricks, how you cool down your aerosol, how you deal with different practical aspects. So, there J (researcher) and E (leader) got pretty good working experience, working with these aerosol reactors that we have here. And after they went back to Finland, we had some correspondence over the e-mail about some questions and doubts. They also ordered the same sort of reactor [for themselves] in 1993. (AG/28.10.1997)

The Americans learned from the joint experiments the use of aerosol measurement devises. The Finnish group mastered the use of two aerosol measurement devices; the impactor and differential mobility analyzer (DMA), for particlesizedistribution. TheFinnish group also mastered the use of an electrostatic precipitator, which directed theparticles straight onto the grid of the electron microscope. Theuse of thesedevices in the experiments made it possible to separate particles of different sizes for further analysis. From the American group a graduate student reported:

We knew about impaction, but we did not use impactors in our reactors to improvethecharacteristics of the powders that we made. Sure it is a known thing-people haveused impactorsfor the last 15 years. But it was a good thing that came out it that you could make better powders. (...) When $\mathrm{E}$ was here in January 93, I also learned the use of electrostatic precipitation to collect powders. He had his set-up from Finland to collect powders directly onto SEM (scanning electron microscope) grids. He had this very nice set-up to do that. (AG/ 26.2.1997)

The two excerpts show that the knowledgetransferred between the Finns and the Americans was related to the use of the research instruments, thus personal visits were necessary to teach the skills needed in the experiments. Harry Collins (1974: 177) analyzed the invention process of theTEA laser and noticed that laboratories succeeded best through reciprocity, either by personal visitsand telephonecallsor bythetransfer of personnel. Traditional sources of information, such as published literature and journals, carry already-established knowledge, but they seldom carry current information of "the frontiers" (Kreiner \& Schultz, 1993: 202). In order to learn the skills necessary to use unfamiliar research equipment, thejoint experiments were necessary for the researchers.

Later, in 1993, with thehelp of the Professor T from New Mexico, the Aerosol Technology Group designed and built its first spray pyrolysis reactor. It was thus possible to start experiments in the ATG's own laboratory. Also, the electron microscopes were needed to characterize the shape, morphology, size and elements of nanosized particles. The ATG researchers at first tried to analyze them with the Helsinki University of Technology and the University of Helsinki electron microscopes. However, their resoIution was not good enough, and the particles were hardly visible. The leader of the ATG resolved this problem, by traveling once a year to the American group with his group's particle samples and analyzing them using the university's electron microscopes.

All in all, collaboration between the American and the Finnish research groups was based on the complementarity of their instruments and the knowhow related to using them. The Finns gained morefrom thecollaboration than the Americans. Interaction with the 
American group gave the Finnish group a good start for expanding to a new research area.When the American Professor T visited Finland, he was also a promoter, speaking about the new nanotechnology research to people from funding agencies. The personal relationship between the group leaders became quite close. The Finnish visitors even stayed at theAmerican professor's home during their visits to Albuquerque.

\section{The Critical Tum in Collaboration During a Visit in Spring 1997}

By 1997, the conditions of collaboration between the research groups had significantly changed. I had an opportunity to acquire data about this change, by observing a Finnish group leader's visit to theAmerican group during my fieldwork period at the University of New Mexico. I collected data about the visit by interviewing the group leaders before and after their encounter. I video recorded the discussions between the Finnish visitor and the American researchers and their group leader. I followed the Finnish group leader to lunches

and made notes about discussions. The visit lasted from Wednesday evening, until the following Monday afternoon, with the official discussions lasting two days at the university. After the weekend, there was one closed meeting with an investor of the start-up company, which I was not allowed to observe.

\section{Expectations of the Visit}

In spring 1997, the leader of the Finnish research group was planning to visit the American research group on his way elsewhere in the USA. Up to this point, the Aerosol Technology Group had proceeded in the new research area of aerosol synthesis of materials. They had acquired a new scanning electron microscope (SEM) and they were about to havea new transmission electron microscope (TEM) installed. Consequently, theFinnish group leader did not need to use the American's electron microscopes. The Finnish group had started to design a pilot-scaleaerosol reactor of its own, which was thefirst step towards an industrially scaled-up production method. The group leader had also created contacts with potential users of new materials, such as a Finnish medical company. Now, his main goal wasto visit three American medical companies on the west coast and learn their state-ofthe-art methods of production. After this, he wanted to meet with the American research group. This is how he described his expectations aboutthe forthcoming visit:

Whatam I going to discuss with T?Well,
I want to know what material they are
planning on making there. Now, I al-
ready have some kind of idea about it,
about how their scaled-up reactor in
the start-up company is developing. I
want to see how it is going there. Then
T wants to introducemeto someinves-
tor guys, who havejoined his company.
It is good to meet them, you never know
whether itis useful or not. Then, I want
to see what they are doing in the uni-
versity, talk with the students. I met a
few of them in Orlando, and their stud-
ies did not seem so wonderful any-
more. I felt that their SEM and TEM
things werequite primitive, whileat the
sametime we havelearned to do them
and we have moved forward here too.
It isthesamewith thereactor. Weknow
a lot about it. We have a big modeling
team pondering about it. Then I want 
to go to the west coast, to see three important medical companies.... (E/ 24.1.1997)

This excerpt shows that the Finnish group leader came to meet with the American research group to learn something new, but, at the sametime, he had a tendency to compare his group's abilities to the American group. The phrases reflecta competitive, as well as a collaborative situation between these two groups. The Finnish group leader was expecting open communication about the scale-up process of the material reactors, which they were about to start in the ATG. He also wanted to check the level of research in the American group.

About a month before the Finnish group leader's visit, the American group leader described hispoint of view about their collaboration:

- What kind of collaboration do you do with E's group nowadays?

- Well, lately nothing. The very simple reason for that is that it is 5000 miles away. That's the main reason. Why we collaborated in the past was the same reason I collaborated with $M$ : M knew something we didn't and I knew something he didn't. By putting those together both sides got something more than if they had done it themselves.

- So what did you get from ATG?

- They have much expertise in instruments, measuring. They are able to measuresomething: size of the particle, number of particles of certain size, in a certain volume of gas. That is a very specialized expertise that you need to develop over theyears and have a number of people working on. I choose not to do that in my work, becauseyou can't do everything, so I chose a different emphasis. E's group does not understand very much about what materials are interesting to make. We know what materials are interesting to make, but we don't have the sophisticated methods to measureaerosol characteristics. But we also have more technique for looking at materials in general. Hedoes not have... he is getting better now, cause he is getting SEM and TEM, but he still has a huge, a long way to go. So we have a lot of instruments that he is not able to use. (T/ 3.2.1997)

From the American group leader's perspective, the collaboration with the Aerosol Technology Group was not in an active phase. By emphasizing that his group is ahead of the Finns, in the materials field, the American professor expressed the competitive atmosphere between the groups. The obvious reasons for the diminishing collaboration werethegeographical distance between the groups, and lack of time, as T expressed later in the same interview: "He has gotten busier and I have gotten busier". The American professor knew that the Finns had now set up systems and learned to makethematerials themselves. Based on this background, it was unclear to the American professor why the Finnish group leader wanted to visit their group. In the interview he said:

- So why isE coming herein March?

- I'm not sure. I don't know why he is coming. I know he is coming because of another reason and so he is coming by here. I recommended to him that I would introduce him to somebody, who is very well connected in the US and knows a lot of people, with a lot of moneyon the business side. Who isinterested if somebody has inventions that could be turned into businesses. $\mathrm{He}$ is the guy. That is the main thing I could give to $\mathrm{E}$. (T/ 3.2.1997)

Just two weeks before the visit, the American group leader mentioned that he did not expect much more collaboration with the Finns. 
- I don't see that very much is going to happen in the future, because Finland is so far away, too many miles.

- But $\mathrm{E}$ is going to visit here..

- Yes, but again he is not visiting on the point of view of doing research. It could be that. I don't know about his intentions.Wetry to do whatever makes the most sense. If something does not make any sense, we just don't do it. I'm not going to have collaboration to sayl have a collaboration, if that is something illogical. ( $T /$ 4.3.1997)

This excerpt also shows the contradictory and unclear expectations of the American group leader, regarding the visit. He says: "He [the Finnish group leader] isnot visiting on the point of view of doing research." But, he continues that it could be that, and that he actually does not know the Finnish visitor's intentions.

Nine days before the visit, the leader of the American group began to prepare for the visit, by sending an e-mail to his own group. In thee-mail, heencouraged thestudentsto discusstheir studies with the Finnish visitor, while at the same time warning them against disclosing anything proprietary:

To the aerosol people: Dr. E, an expert on virtual impactors and impactors along with aerosol characterization in general, is visiting us for two or three days. This is an opportunity to discuss your UNM research with him and get some ideas. I suggest that B (Ms student), Su (Msstudent), D (Msstudent), J (Msstudent), A (Ph.D. Student), S (MS Student), Sa (Ph.D.Student), etc. use this as practiceto not discloseanything proprietary, while getting information from him. Pleaselet meknow if you are interested in speaking with him. (Email from $T$ to the group 11.3.1997)

All in all, the expectations of the visit of the Finnish group leader were reserved, but open from the viewpoint of the American group leader. Neither of the group leaders knew about each other's expectations before the visit. Only discussions between theFinnish visitor and the Americans would define the direction of their future collaboration.

\section{A Puzzling Encounter between the Finnish and the American Group Leader}

Thetechnical editor of the American research group reserved half an hour to an hour, for seven of the graduate students and for three postdoctoral fellows to have a conversation with the Finnish visitor. The program was given to the Finnish group leader on his arrival day, March 20th. However, the program was not followed as planned during the two days of the visit. One of the graduatestudents, who was working on a study that was under patenting process, canceled the appointment with the Finnish visitor. Another student working for the American professor's start-up company at the time, was unsure if he could talk about his work, so he also canceled the meetingat the last moment. Yet another graduate student who worked from time to time in the professor's company, forbade me to video- or audiorecord their discussion, because of the delicatesituation.

I chose two episodes of the visit under detailed analysis: the interaction between the Finn and an Indian graduatestudent, and the discussion between the group leaders. These were chosen from the data becausethey demonstrate in a compact way, the tensions in the atmosphere, and reasons for hindrance in the communication. 
The last discussion on the first day, was with an Indian graduate student. It was themost rewarding conversation for the Finnish group leader. They talked about modeling concerning the aerosol synthesis of materials and after the discussion they decided to go around the laboratory to see the instruments. The Finnish visitor noticed that the equipment for the aerosol measurements wereleft untouched in thelaboratory, as an excerpt from thefield notes describes. We walked around the laboratory room number 009. It waskind of amusing that $E$ found a DM $A^{5}$ left alone in the corner. The last time it had been in use was two years ago, when $\mathrm{E}$ had visited the group. $E$ took a piece of post-it note from the side of it and laughed. "Yes, this is my handwriting", he said and continued: "Has anyone used our impactor ${ }^{6}$ ?" The graduatestudent answered: "No." (Field report 20.3.1997)

This incident revealed that the complementarity and exchange between the research groups was vanishing. The American researchers were not interested in aerosol measurements anymore. During the round of the laboratory, the graduate student apologized that he actually did not know what the others in the group were studying. "Those who work for the professor's company keep very closed mouths, so information is not flowing", he said.

The short interaction between the Finnish group leader and the American group leader is analyzed in detail in the following. Duringthefirst day of thevisit, the group leaders went to lunch together. After lunch, the program called for an "official" discussion in the American professor's office. I video recorded ${ }^{7}$ the discussion from its beginning, for a duration of five minutes. The leaders were expected to talk about the state of their mutual collaboration and issues involved with it.

In order to understand what happened in the interaction between the group leaders, part of the discussion from the beginning is analyzed in depth from the videotape. It seemed that the atmosphere was uneasy and that the conversation was aloof. In the following analysis, the elements that express tension between the leaders are pointed out. Table 1 presents the transcript of the discussion and the nonverbal communication.

\section{Turns 3-8}

Topensthe conversation with a general question: What are we going to talk about? E appears somewhat surprised, because he answers first: yeah, well, $\mathrm{hmm}$. He then says that he has not thought of a topic. This communicates that the Finnish group leader had not prepared for the conversation. T's reaction is more stiff, in turn 7: Well, you'd better start thinking about it. It is worth noticing that he uses the word you, now instead of we, as if regarding the topic as not his or their common task. The half-hearted tone is strengthened by a non-verbal movement: $T$ glances his watch and continues that they have reserved twenty minutes for the meeting.

\section{Turns 9-21}

E figures out a safe and obvious topic to start with - the schedule of his visit. He asks, in turn 9, about the overall program outside the program paper, which is in his hand. $T$ answers that they have a meeting with an investor, which he had mentioned earlier. Then E asksabout the 
Table 1. The discussion between the American professor and theFinnish visitor 20.3.1997

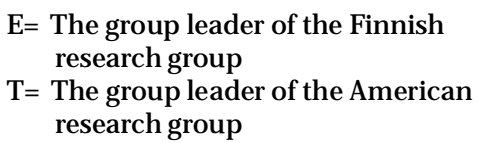

\section{Verbal interaction}

3)T: So what are we going to talk about?

4)E:Yeah, well, hmm.

5)T: Eh.

6)E: I didn't think too much of that, yet. I am on kind of a holiday.

7)T: Well, you'd better start thinking about it or we gonna be sitting here for twenty minutes.

8)E:Yeah.

9)E: How have you planned the schedule other than this. On Monday?

10)T: On Monday we have that guy I told you about, from Machintosh=

11)E: $=$ Okay.

12) $\mathrm{T}$ : We have established the time. Machintosh.

13)E: That's right, yeah, okay.

14)E: And tomorrow there's that seminar?

15)T: Well, you know, I talked with Diptarkha about that. He can't give that seminar if you are going to be there. Or either you can't come to that seminar or he has to get different topic.

16)E: Okay, I can drop it out, yeah.

17) $T$ : The reason being is that, that is nonpatented. They are working on a patent right now and if they give that seminar and somebody from outside of university attends, they can't file the patent in

Europe and Japan and all that, so

18)E: I can drop it out. It is not a big deal, so..

19)T: Maybe you can talk to Mark earlier than that=

20)E: =Yeah, yeah.

21)T: instead of two thirty, three thirty.

\section{Nonverbal communication}

$\mathrm{E}$ and $\mathrm{T}$ aresitting at thetablefacing each other.

E glances at thecamera and laughs.

T looks at the program paper, folds it, puts it on thetableand glances at his watch.

T leans back in hischair, takes his calendar from his backpocket and putsit on thetable

T rests hischin on hishand and sips coffee.

T points the program paper on the table. E sips coffee.

E leans back in hischair with hislegs crossed.

T points at theprogram paper.

T shrugs his shoulders and takes the program paper to his hands, looking at the paper. 
Table1.continued

Verbal interaction

22)T: What are you going to talk with Abhijit, ha?

23)E: I want to see what he is doing with the modeling part and all. Also with the $\mathrm{N}$ [the start-up company] stuff, how things are running, so

24) $\mathrm{T}$ : Well, he is not probably going to tell you much...

25)E: Okay, okay.

26)T: about N[the start-up company] stuff, so. It depends what you are trying to learn, I suppose. And we need to talk to this Machintosh guy on Monday in order to understand what your relationship

27)E: Okay.

28)T: is going to be.... with all these

29)E: Okay, yeah.

30)T: different creatures [refers the start-up company] that have been formed. (3.0)

32)E: That's very short, yeah.

33)T: That's good. That was it.

(1.0) I am serious. I don't know what else we should talk about right now. (.)I didn't have really any real big plan or anything like that.

34)E: Uhmm, yeah.

\section{Nonverbal communication}

Tholds thepaper in his hand, looks at the paper and touches his nose. Herestshischin on his hand.

E sits leaning back.

E looks at T and nods twice.
T looks at the program paper, the paper in hishands. T shifts the paper away, takes his coffeecup and looks past $\mathrm{E}$.

T givesa quick smileand glances $\mathrm{E}$.

T sips his coffeeand puts thecup on thetablewith a sound.

T smiles and looks at E.

T smiles and looks at the camera.

T lifts his hands up, brings them down again and grabs the program paper with both hands.

E breaths heavily, lifting his arms behind his neck, leaning back. E grimaces and looks down. seminar in the program. Surprisingly, $T$ answers indirectly that $E$ is not allowed to participate in the seminar. In a metaphorical sense, the door has slammed in E'sface. Theimpoliteimpression is then softened by T offering an explanation of a patent-pending. $E$ indicates that he does not mind actually. Throughout the whole topic, T looks intently at the program paper and avoids looking at $\mathrm{E}$. The program paper becomes like a barrier between the leaders.

\section{Turns 22-30}

$T$ asks what $E$ is going to talk about with the graduate student, who used to do joint experiments with $E$, and who is currently working in the professor's firm. $E$ answers quite straight forwardly, that hewants to ask aboutthe American firm. Again, T gives a negative reaction to this. Metaphorically: a second door is slammed in E's face. E seems to surrender. $T$ continues about the need to talk 
to the investor guy in order to understand what their relationship is going to be. This indicates he wants to define their relationship in terms of E signinga confidentiality agreement with hisfirm.

\section{Turns 31-34}

After a three second pause, $T$ interprets the situation, that they do not have anything more to discuss. T already tries to finish the conversation, which had now lasted only two minutes. However, in the beginning it was revealed that both parties had twenty minutes reserved for the meeting. E mutters his agreement in spite of the shortness of the conversation. T continues to affirm that the conversation has ended, by saying; "That's good. That wasit." E seems disappointed by grimacing. However, the conversation started to flow again about the program and about the graduate students, in turns 35-71.

Using Per Linell's (1990) dimensions for analyzing patterns of asymmetry in dialogues, the interaction between the group leaders could be interpreted as asymmetrical and dominated by the American party. Even in this short excerpt, the first official discussion between the group leaders, it was evident how uncommunicative and reserved their relationship had become.

But how did the situation end between the leaders? The situation lasted for two more minutes (turns 35-73). The Finnish group leader wanted to identify the graduate students he was going to have discussions with. The group leaders also discussed the problems of one of the graduate students. This topic raised a mutual feeling of collegiality, but only for a moment. Then $\mathrm{E}$ suggested they would continue the discussion without the camera, probably hoping that they could discuss in a more relaxed atmosphere. I left the room with my camcorder, and the discussion between the group leaders continued behind a closed door. According to my notes, they talked mainly about establishing a possible confidentiality agreement.
After 20 minutes $T$ and $E$ came out of the room and they looked for graduate student J. We did not see him around, so we went out in the yard to wait. $\mathrm{E}$ said to me:"Oh, how tense $T$ is. It is so hard to start a conversation. He begins to wonder what kind of papers I should sign to protect confidentiality. And I don'thaveany intentions to harm them or to benefit from their patents." $E$ was surprised how restricted the atmo- sphere had become in two years and how frightened the students were to reveal anything. (Field report 20.3.1997)

From this entire interaction, the group leaders realized how much their relationship had changed. There was now more to hide, than to reveal to each other. Oneway to redefinetheir relationship, was a suggestion to sign a confidentialityagreement, which would have created new rules for future collaboration between the group leaders.

Impressions of the Group Leaders after the Visit

In the last day of the visit, I interviewed both group leaders about what they had benefited from during the visit, and why their collaboration was about to vanish. The different perspectives of the group leaders are written in a concise form in table 2.

The Finnish group leader's discussions with the American graduate stu- 
Table2. Concepts about the visit from the American and the Finnish group leaders' perspectives

\begin{tabular}{|c|c|c|}
\hline Concepts of the visit & $\begin{array}{l}\text { Finnish group leader's } \\
\text { perspective }\end{array}$ & $\begin{array}{l}\text { American group leader's } \\
\text { perspective }\end{array}$ \\
\hline $\begin{array}{l}\text { Discussions with the } \\
\text { graduate students }\end{array}$ & $\begin{array}{l}\text { - I gained new references } \\
\text { about the spray pyrolysis } \\
\text { mechanism from a graduate } \\
\text { student. }\end{array}$ & $\begin{array}{l}\text { - Probably, the graduate } \\
\text { students learned something } \\
\text { from the discussions with E. }\end{array}$ \\
\hline $\begin{array}{l}\text { Forming a potential } \\
\text { shared research object }\end{array}$ & $\begin{array}{l}\text {-We talked about droplet's } \\
\text { morphology, but T is not } \\
\text { going to study it. } \\
\text {-I learned nothing about the } \\
\text { scale-up process. } \\
\text { - We did not talk about flows } \\
\text { in the reactor or producing a } \\
\text { droplet. }\end{array}$ & $\begin{array}{l}\text { - We found fundamental } \\
\text { areas to study, but the } \\
\text { complex part is to find who } \\
\text { is going to study those and } \\
\text { who is going to pay for it. }\end{array}$ \\
\hline $\begin{array}{l}\text { Reasons to end the } \\
\text { collaboration }\end{array}$ & $\begin{array}{l}\text { - The openness is gone. } \\
\text { - T puts his effort into } \\
\text { commercializing now. } \\
\text { - T does not see the } \\
\text { importance of studying } \\
\text { fundamental things, if he } \\
\text { does not see the connection tc } \\
\text { the research application. }\end{array}$ & $\begin{array}{l}\text { - E has his own equipment } \\
\text { and SEM, and that was the } \\
\text { last reason for coming here. } \\
\text { - Aerosol measurements are } \\
\text { too time-consuming for us } \\
\text { and they add nothing of } \\
\text { scientific value to our } \\
\text { research. } \\
\text { - We are both too busy to } \\
\text { collaborate. } \\
\text { - E has a different motive } \\
\text { from ours in his research. }\end{array}$ \\
\hline $\begin{array}{l}\text { Attitudes about the } \\
\text { emergence of the start-up } \\
\text { company }\end{array}$ & $\begin{array}{l}\text { - } T \text { and } M \text { are going to make } \\
\text { good business and they } \\
\text { become rich, but I doubt that } \\
\text { they will be able to return to } \\
\text { the university after that. }\end{array}$ & $\begin{array}{l}\text { - I was annoyed that E kept } \\
\text { asking about my firm. } \\
\text { Doesn't he understand I } \\
\text { can't talk about it? }\end{array}$ \\
\hline
\end{tabular}

dents remained quite thin. The Finnish visitor mentioned that the most beneficial information he received was some relevant references from a graduatestudent. A potential new research object was not formed in the discussions between the leaders. The scaling-up process as a topic was avoided in the conversations, because it was a potential competitive issue between the Finnish research group and theemerging American firm. The change in emphasis upon commercialization versus researching fundamental things, by the American research group and the start-up company, became visibleto the Finnish visitor during his visit. The American group leader explained how the basis of the complementarity of instruments between the research groups had disappeared. The Finnish group leader expected that thestart-up company would makea good business, but the entrepreneurial professors would not be able to 
return to university research after that. The American group leader found the Finnish visitor's questions abouthis firm intrusive. It should be reminded that the American professor was involved in a very contradictory situation during

the visit. He was a professor in a research group, in which the dominating norm was free flow of knowledge while, on the other hand, he was a manager of a small firm, which needed to protectits know-how from the competitors. It is thus understandablethat heallowed the Finnish visitor to talk with his graduate students but did not allow him information about the firm's business. The American group leader was facing a stressful situation, that of transforming from a professor to an entrepreneur, and this influenced the atmosphere of the Finnish leader's entire visit.

\section{Conclusions}

Figure 4 depicts the changed situation between the American research group, the start-up company and the Finnish research group, by using the triangular structure of mediated activity.

The top arrow refers to the apparata of thetwo research groups. In the beginning, collaboration was founded on complementary know-how, based on each having different kind of research equipment. From the American perspective, one reason for ending the collaboration was that they did not need, or have time for, the aerosol measurements they used to do with their Finnish partners. On the other hand, the Finnish research group had acquired equipment of their own for aerosol synthesis and particlecharacterization and,

Figure 4. Collaboration in transition between the American and the Finnish aerosol research groups in 1997

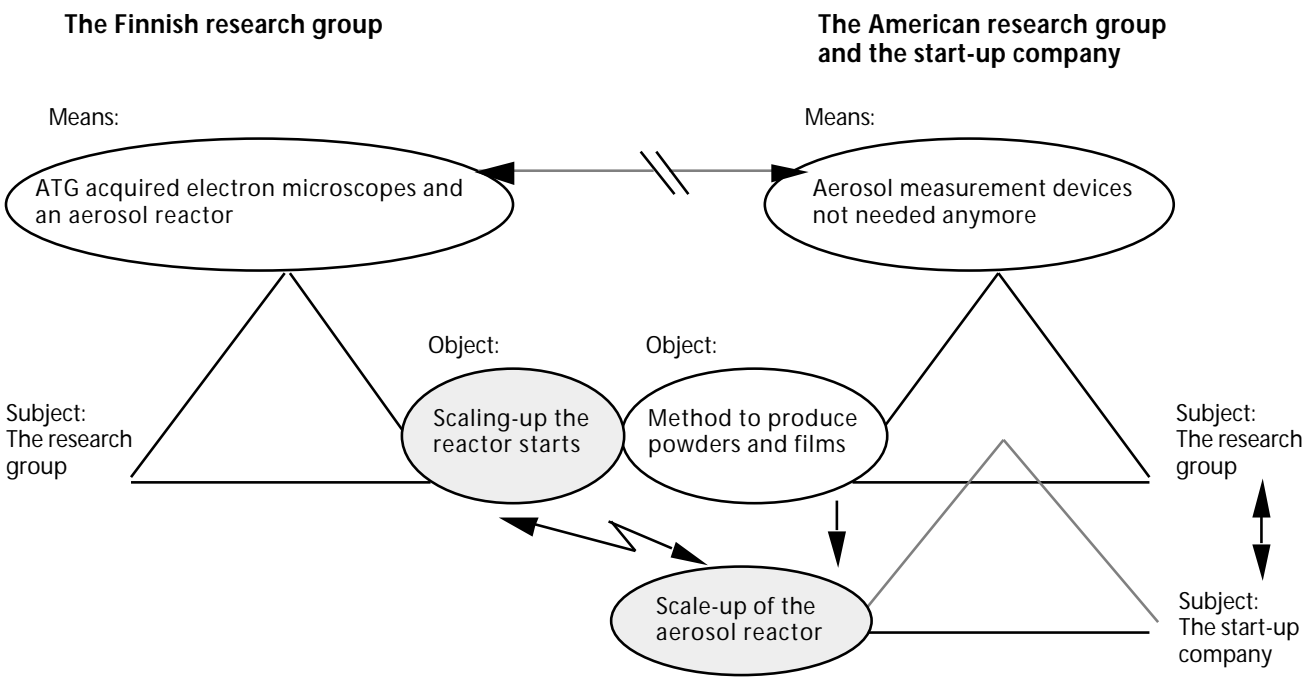


therefore, were no longer dependent on the American group's facilities. The complementarity based on instrumental know-how had become obsolete between the research groups.

From the viewpoint of doing research and exchanging information, a potential shared research object was not formed, although the group leaders did find some similar research interests. In the American group, the graduate students were about to finish their dissertations, so new research topics werenot relevant at the time. The Finnish group leader could not learn anythingfrom thescaleup process, because that was one of the protected core competencies of the American start-up company. The Finnish group leader was not invited to see the pilot scale reactor in the American start-up company during the visit. The start-up company's and the Finnish research group's objects had now become competitive. Also, the rules of research collaboration respecting and allowing thefreeflow of information had changed since the start-up company came into the picture. The institutional and cultural differences between Finland and the USA explain partly the competition between theFinnish research group and the American spin-off firm. It is more usual that American researchers have the possibility and the desire to benefit financially from the technology they are developing. TheFinnish group is located in a public research center, whose mission is to do applied research and serve the industry, therefore the scaling-up of the aerosol reactor takes obviously place inside theVTT laboratory in contract research projects.

Over the years, the American professor and the Finnish group leader developed different motives for doing research work. The American professor

Table3. Developmental phases of research work and motives to collaborate between the Finnish and the American research groups in 1993 and 1997

\begin{tabular}{|c|c|c|c|c|}
\hline & $\begin{array}{l}\text { FIN: } \\
\text { Developmental } \\
\text { phase }\end{array}$ & $\begin{array}{l}\text { Motiveto } \\
\text { collaborate }\end{array}$ & $\begin{array}{l}\text { USA: } \\
\text { Developmental } \\
\text { phase }\end{array}$ & $\begin{array}{l}\text { Motiveto } \\
\text { collaborate }\end{array}$ \\
\hline 1993 & $\begin{array}{l}\text { Getting started } \\
\text { in a new } \\
\text { research area }\end{array}$ & $\begin{array}{l}\text { Hearning to use a } \\
\text { spray pyrolysis } \\
\text { reactor and electron } \\
\text { microscopes and } \\
\text { writing joint } \\
\text { publications }\end{array}$ & $\begin{array}{l}\text { Dissemination of } \\
\text { research results and } \\
\text { getting } \\
\text { international } \\
\text { reputation }\end{array}$ & $\begin{array}{l}\text { +Learning to use } \\
\text { impactors and } \\
\text { DMA and } \\
\text { getting more } \\
\text { detailed data on } \\
\text { production of } \\
\text { fullerenes and } \\
\text { superconducting } \\
\text { powders }\end{array}$ \\
\hline 1997 & $\begin{array}{l}\text { Expanding the } \\
\text { application } \\
\text { related network } \\
\text { and finding } \\
\text { new } \\
\text { applications }\end{array}$ & $\begin{array}{l}\text { +Learning what } \\
\text { materials the } \\
\text { Americans are } \\
\text { working on and } \\
\text { seeing how the } \\
\text { scaled-up reactor } \\
\text { has been developed }\end{array}$ & $\begin{array}{l}\text { Commercialization } \\
\text { of the new } \\
\text { technology }\end{array}$ & $\begin{array}{l}\text {-Keeping the } \\
\text { scale-up process } \\
\text { secret and not } \\
\text { revealing } \\
\text { anything } \\
\text { proprietary }\end{array}$ \\
\hline
\end{tabular}


wanted to put his main effortsinto commercializing theaerosol method for production of materials, while the Finnish research group leader wanted to expand his research group to a new research area. Table3summarizes themotivesfor collaboration and the different stages of development between the two research groups.

When linking the development of the research group and the groups' motives to work together, it seems understandable that collaboration flourishes when the research group is in an expansive phase. As Atkinson et al.(1998) state, when new lines of research are mapped out in the initial phase of the research groups, the social relations seem to be more open and relaxed. On the other hand, it is obvious that guarding your corecompetence becomesmoreimportant when there is a financial interest involved.

The interaction between the research group leaders proved how inhibited and uncomfortable communication becomes in an atmosphere of competition and secrecy. The relationship that had been a friendship in the past, became more complex because of the sense of rivalry between the Finnish group and the American firm. The scheduled conversation exemplified a situation where hidden tensions between the group leaders became visible. Although the motives of collaboration reflect the different developmental trajectories of the research groups, it was only in theinteraction between theleaders that they collided. That interaction was also a moment when the research collaboration could have been re-established.

This case study demonstrates the vulnerability and temporality of research collaboration. The collaboration and trust between research groups is never astablestate. Theanalytical power of the cultural-historical activity theory was proven to be strong in the analysis of a trajectory of collaboration. The activity theoretical framework made it possible to combine the historical development of the two research groups to the situational interaction analysisin their critical phase of the collaboration. The concept of mediated activity was used in the analysis. It focused on the evolution of the object and the system of means (theories, instruments, methods) of the two groups. The preconditions of collaboration became visible through analyzing changes in the research objects and in complementarity of the tools and methods between the two research groups. However, it must beemphasized that the developmental paths of the groups, or thechanges in their tools and objects, do not predetermine the direction of their collaboration. Before the encounter, the group leaders were not aware of each others groups' stage of development and did not anticipate the course of events. It is in the social interactions between the members of the research groups that the rules of the changing relationship are concretely negotiated and constructed. That is why we need to capture those critical moments of interaction, where these turns and changes really take place.

\section{Acknowledgements}

This paper is part of my dissertation study written in the Doctoral Program of Developmental Work Research and Adult Education in the University of Helsinki. I would like to thank the members of the two research groupsfor a positive attitude 
towards my fieldwork. I am grateful also to Professor Reijo Miettinen, Professor Yrjö Engeström, and my colleagues Mervi Hasu, Juha Tuunainen and Janne Lehenkari for beneficial comments of earlier versions of this paper. Versions of this paper have been presented at the Fourth Congress of the International Society for Cultural Research and Activity Theory in Aarhus, Denmark, June 7-11, 1998 and at the European Association of Social Studies of Science Conference in Lisbon, Portugal, October 1-3, 1998.

\section{Notes}

1 Video was used in collecting the interactional data, because it is a particularly valuable tool when we are interested in what "really" happened, rather than in accounts of what happened (Jordan \&Henderson, 1994: 12). In activity theoretical studies, video recordings makes it possible to collect data from complex real world settings, and the data could also be shown afterwards to the actors of the setting for the basis of learning.

2 The terms expressing different aspects of the object of activity are objective, purpose, motive, horizon of possibilities and object hypothesis. For the concept of activity and its epistemological significance, see Leontjev, 1978: 50-54 and 62-67, and Miettinen, 1998: 424-425.

3 These are counted from the curriculum vitae.

4 Nanosized particles are those with a diameter of 1-100 nanometers (10-9 meters).

5 DMA is differential mobility analyzer, used for measuring particle size distribution.

6 Another devise used for measuring particle size distribution.

7 One could ask whether the group leaders' interaction was influenced by the presence of a camera. Experience shows that people habituate to the camera surprisingly quickly (see Jordan \& Henderson,
1994: 17). I asked permission to video record the leaders' discussions in advance, having already used a camcorder in my fieldwork for several months in both research groups. The delicate situation between theleaders probably became out even more uncomfortable with the presence of me and the camcorder, but the breaking down of the collaboration would have happened even without the camera.

\section{References}

Atkinson, P., Batchelor, C. \& Parsons, E.

1998 "Trajectories of collaboration and competition in a medical discovery." Science, Technology \& Human Values, 23, 3: 259-284.

Collins, H.M.

1974 "The TEA set: Tacit knowledge and scientific networks." Science Studies 4: 165-186.

Dickson, K.

1996 "How informal can you be? Trust and reciprocity within co-operative and collaborative relationships." International Journal of Technology Management, Vol 11, Nos 1/2, 1996.

Engeström, Y., Brown, K., Christopher, L.C. \& Gregory, J.

1991 "Coordination, cooperation and communication in the courts: Expansive transitions in legal work." The Quarterly Newsletter of the Laboratory of Comparative Human Cognition, 13, 4: 88-97.

Gurav, A.G., Kodas, T.T., Wang, L-M., Kauppinen, E.I. \&Joutsensaari, J .

1994 "Generation of nanometer-size fullereneparticles via vapor condensation." Chemical Physics Letters 218 (1994): 304-308.

von Hippel, E.

1987 "Cooperation between rivals: Informal know-how trading." Research Policy, 16: 291-302.

Hull, D.L.

1988 Science as a process. An evolutionary account of the social and conceptual development of science.Chicago: The university of Chicago Press. 
Jordan, B. \& Henderson, A.

1994 Interaction analysis: Foundations and practice. IRL report No.94-0027, July 1994. Palo Alto: Institute for research and learning.

Katz, J.S. \& Martin, B.R.

1997 "What is research collaboration?" Research Policy, 26:1-18.

Kraut, R.E., Edigo, C. \& Galegher, J.

1990 "Patterns of contact and communication in scientific research collaboration." Pp. 149-171 in Galegher, J., Kraut, R.E. (eds.) Intellectual teamwork. Social and technological foundations of cooperative work. Hillsdale, New Jersey: Lawrence erlbaum associates.

Kreiner, K. \& Schultz, M.

1993 “Informal collaboration in R\&D. The formation of networksacross organizations." Organization Studies. 14, 2: 189209.

Leontjev, A.N.

1978Activity, consciousness and personality. Linell, $P$. Englewood Cliffs, N.J.:Prentice Hall.

1990 "The power of dialogue dynamics." Pp.147-200 in Markova, I. and Foppa, K. (eds). The dynamics of dialogue.Great Britain: Harvester Wheatsheaf.

Lynch, M.

1985 Art and artifact in laboratory science. A study of shop work and shop talk in a research laboratory. London, Boston, Melbourne and Henley: Routledge \&Kegan Paul.

Meadows, A.J . \& O'Connor, J.G.

1971 "Bibliographic statistics as a guide to growth points in science." Science Studies 1: 95-99.
Miettinen, $\mathrm{R}$.

1998 "Object construction and networks in research work: The case of research on cellulose degrading enzymes." Social Studies of Science, 28, 3: 423-463.

Pao, M.L.

1980 “Co-authorship and productivity." Proceedings of the American Society for Information Sciences 17: 279-289.

Sinha, D.K. \& Cusumano, M.A.

1991 “Complementary resources and cooperative research: A model of research joint ventures among competitors." Management Science, 37, 9:1091-1106.

Teichert, $\mathrm{T}$.

1997 “Success potential of international R\&D co-operations." International Journal of Technology Management, Vol.14, Nos 6/7/8: 804-821.

Vygotsky, L.S.

1978 Mind in society: The development of higher psychological processes. Cambridge, Mass.: Harvard University Press.

\section{Eveliina Saari}

Center for Activity Theory and

Developmental Work Research

Department of Education

University of Helsinki 